\title{
Effects of different packaging techniques on the microbiological and physicochemical properties of coated pumpkin slices
}

\author{
Filiz AKSU ${ }^{1 *}$, Harun URAN²${ }^{2}$, Dilek DÜLGER ALTINER², Sema SANDIKÇI ALTUNATMAZ
}

\begin{abstract}
In this study the effects of zein film coating along with benzoic acid on the quality of sliced pumpkin samples, which were packaged with different techniques were investigated. The samples were allocated into different groups and were treated with different processes. Following processing, the samples were stored at $+4{ }^{\circ} \mathrm{C}$ for twenty days. Physicochemical and microbiological analyses were carried out on the samples once every five days during the storage period. According to color analysis, the $\mathrm{L}^{*}$ value was observed to have significantly decreased in the processed and packaged samples in comparison with the control group. Besides, $\mathrm{a}^{\star}$ and $\mathrm{b}^{*}$ values increased in all groups. It was determined that zein film alone did not exhibit the expected effectiveness against moisture loss in the samples. According to the results of microbiological analysis, a final decrease at approximately $1.00 \mathrm{log}$ level was determined in total count of mesophilic aerobic bacteria (TMAB) in the group which was vacuum packaged in PVDC with zein coating when compared with the initial TMAB. Furthermore, no molding occurred in zein-coated group on the last day of the storage period, while massive mold growth was noted in the group which was packaged without any pretreatment procedure.
\end{abstract}

Keywords: edible film; zein; packaging; pumpkin.

Practical Application: Zein film coating technology should be considering to conservation the pumpkin slices.

\section{Introduction}

Pumpkin, which is a member of the Cucurbitaceae family, constitutes the majority of edible plant species (Oloyede et al., 2012). It is a good source of carotene, soluble vitamins and amino acids and contains relatively low dry matter, ranging from $7 \%$ to $10 \%$. The chemical composition of pumpkin which is rich in antioxidants and vitamin offers a health protective effect (Guine et al., 2011).

In Turkey, pumpkin (Cucurbita moschata Duch.) is a major vegetable species belonging to Cucurbitaceae family (Balkaya et al., 2010). It is rich in carotenoids and minerals such as calcium and potassium and has very low sodium content. With these features, it is a valuable nutrient resource which can also be used as a food additive (Gurbuz \& Evranuz, 2006).

However, despite its high nutritional value and apart from being a favorable vegetable, the storage procedure of pumpkin is troublesome. Pumpkins are still preserved at storages or in cooling rooms mostly under uncontrolled conditions. Sliced storage procedure is utilized to enable extended shelf life and convenience in consumption. However, the shelf-life of pumpkin is inevitably reduced with slicing process due to the enzymatic and microbial reactions. Undoubtedly, various packaging techniques to be applied after slicing are likely to extend the preservation period of the product. Moreover, lately developed processing systems in food technology like edible coatings are to provide prolonged safe preservation of the products.
Edible coatings are ultrafine, non-synthetic and biodegradable preservative membranes which are produced from natural sources to prolong shelf-life and nutritional quality of foods by regulating moisture content and solid-gas mobility, when applied over the surface and on to the inner layers of the products (Işık et al., 2013). Edible coating films have recently become an interesting subject owing to the accelerating consumer consciousness regarding food safety. These materials are applied to food products via different coating processes and various methods (Torlak \& Nizamlioglu, 2011; Zhong et al., 2014). Novel coating films reduce surface oxygen level and increase internal carbon dioxide concentration of foods. Carbon dioxide is captured within plant tissue during aerobic respiration and thus creates a modified inner condition (Işık et al., 2013). Proteins, lipids and polysaccharides are most commonly used coating materials. Edible films constitute barriers against external factors like humidity, water vapor and oxygen and therefore extend the shelf-life of the food products (Guilbert et al., 1996).

Zein, one of the most important proteins found in corn, is applied as a coating material in processing of hard-shell grains to prevent staling, moisture and oxidative rancidity which results in bitter taste. Edible coatings and films including vax are used to prevent moisture loss, to refine texture and to slow down aerobic respiration in fruits and vegetables. Zein coatings are used in confectionary to sustain optimum moisture content. Collagen 
coatings are applied in sausages to prevent moisture loss, to provide oxygen transfer and to protect uniformity of interior structure, whereas hidroxipropilmethylcelulosa (HPMC) is used to protect food content. Furthermore, HPMC, corn (zein) coatings and gelatin are applied in pharmaceutical industry to improve the appearance and to protect the structural integrity and stability of capsules (Baysal et al., 2009).

There are a limited number of studies available with respect to the application of edible zein as a coating material. In this study, we aimed to investigate the effects of zein film coating process along with benzoic acid on the quality of sliced pumpkin samples, which were packaged with different techniques.

\section{Materials and methods}

\subsection{Preparation of material}

The study material consisted of whole pumpkins (Cucurbita moschata), grown in the Thrace region of Turkey and harvested in fall and then kept out of reach of direct sunlight and stored in a cool, dry storage room until the analysis period. Initially whole pumpkins were washed with hot water and the outer shell surfaces were disinfected in $70 \%$ alcohol. The whole pumpkins were sliced into smoothly cut uniform pieces and the seeds were removed. The sliced samples were processed according to the designed procedures and then refrigerated for 20 days. The control group remained intact but kept in the refrigerator, as well. The following analyses were performed once every 5 days during the storage period and the samples were analyzed in terms of certain physicochemical and microbiological properties.

\subsection{Preparation of coating material and pumpkin groups}

The pumpkin samples were allocated into 6 groups (Table 1), kept at $4{ }^{\circ} \mathrm{C}$ and subjected to the analyses every 5 days. Zein solution was prepared by the method described by (Guilbert et al., 1996). For this purpose, $6.75 \mathrm{~g}$ of dry pure zein (Sigma-Aldrich) was resolved in $40.6 \mathrm{~mL}$ of $95 \%$ ethyl alcohol with a heating magnetic stirrer and elasticity was developed with the addition of $1.9 \mathrm{~mL}$ of glycerin. The solution was stirred for 10-15 minutes and heated up to $70-80^{\circ} \mathrm{C}$. Samples from groups $\mathrm{C}$ and $\mathrm{D}$ were coated with this zein film. Groups E and F were treated with the same solution but this time with the addition of $200 \mathrm{ppm}$ of pure benzoic acid (Merck).

\subsection{Physicochemical analyses}

Ash and moisture contents of the samples were assessed according to (Association of Official Analytical Chemists, 1990). $\mathrm{pH}$ measurements were performed with $10 \mathrm{~g}$ of homogenized samples in $100 \mathrm{~mL}$ pure water for $1 \mathrm{~min}$ homogenizing and $\mathrm{pH}$ values were recorded using a $\mathrm{pH}$ meter-Hanna (Association of Official Analytical Chemists, 1984).

$\mathrm{CIE}^{*}$ (lightness), $\mathrm{a}^{\star}$ (red coloring) and $\mathrm{b}^{\star}$ (yellow coloring) values of pumpkin samples were determined by using Color Flex Hunter Lab Color Measurement System (Hunter Associates Laboratory, Inc.). Five measurements were performed on each seemingly identical (in length) slice and the mean values were calculated (Baysal et al., 2010). CIE Color Values $\left(L^{\star}, a^{*}, b^{*}\right.$ ) are based on a 3 color-scale. $L^{*}=100$ is referred to as white; while $\mathrm{L}^{*}=0$ indicates black. High positive $\mathrm{a}^{*}$ and high negative $\mathrm{a}^{*}$ values are evaluated as red and green coloring, respectively while high positive $b^{*}$ and high negative $b^{*}$ values are represented as yellow and blue, respectively.

\subsection{Microbiological analyses}

For microbiological analyses, $5 \mathrm{~g}$ of samples, which was weighed in the specially designed bag of the blender, were homogenized in $45 \mathrm{~mL}$ of $0.1 \%$ peptone water by using a blender homogenizer (Stomacher 400). Microbiological analyses was simultaneously performed on the subsequent dilutions of the homogenized samples. After the incubation period, plagues containing 30-300 colonies were evaluated $(\log \mathrm{cfu} / \mathrm{g})$. Plate Count Agar (PCA-Merck 1.05463) (72 h at $30 \pm 1{ }^{\circ} \mathrm{C}$ ) was used to quantify total mesophilic aerobic bacteria (TMAB). Violet Red Bile Agar (VRBA-Merck 1.01406) $\left(24 \mathrm{~h}\right.$ at $\left.37 \pm 1^{\circ} \mathrm{C}\right)$ and Potato Dextrose Agar (Merck 1.10130) (5 day at $25 \pm 1^{\circ} \mathrm{C}$ ) were used as selective culture media for coliform bacteria and yeasts/molds, respectively (Harrigan, 1998).

\subsection{Statistical analyses}

Data obtained from the analyses were statistically evaluated with a computer based programme JMP IN 7.0.0 (Statistical Discovery from SAS Institute Inc. (2007), LSD (Least Significant Difference) Test was performed to determine the significant difference between the mean values at the $p \leq 0.05$ level.

\section{Results}

The results of the analyses carried out at the beginning of the procedure (day 0 ) and on days 5, 10, 15 and 20 were indicated in Table 2 and Table 3, respectively.

According to the analyses performed on pumpkin samples prior to the processing and packaging procedures (The control group), $L^{\star}$ (lightness), $a^{\star}$ (red coloring) and $b^{\star}$ (yellow coloring) values were measured to be $77.19,17.14$ and 41.76 , respectively;

Table 1. Group experimental designs for pumpkin samples.

\begin{tabular}{ccl}
\hline Group & Processing Solution & \multicolumn{1}{c}{ Packaging Technique } \\
\hline A & - & Packaging in Polystyrene plates with PVC stretch \\
B & - & Vacuum packaging in PVDC film \\
C & Zein & Packaging in Polystyrene plates with PVC stretch \\
D & Zein & Vacuum packaging in PVDC film \\
E & Zein + Benzoic acid & Packaging in Polystyrene plates with PVC stretch \\
F & Zein + Benzoic acid & Vacuum packaging in PVDC film \\
\hline
\end{tabular}


Aksu et al.

Table 2. The results of color and chemical analyses in all pumpkin groups ${ }^{1}$.

\begin{tabular}{|c|c|c|c|c|c|c|c|}
\hline \multirow{2}{*}{ Sample } & \multirow{2}{*}{ Day } & \multicolumn{3}{|c|}{ Color Analysis } & \multicolumn{3}{|c|}{ Chemical Analysis } \\
\hline & & $\mathbf{L}^{*}$ & $\mathbf{a}^{\star}$ & $\mathbf{b}^{*}$ & Moisture (\%) & Ash (\%) & $\mathrm{pH}$ \\
\hline Control & Day 0 & $77.19 \pm 2.34$ & $17.14 \pm 1.66$ & $41.76 \pm 2.26$ & $94.58 \pm 0.28$ & $0.72 \pm 0.06$ & $6.46 \pm 0.03$ \\
\hline A & 5 & $48.65 \pm 0.01^{\mathrm{f}}$ & $23.60 \pm 0.01^{\mathrm{d}}$ & $43.50 \pm 0.01^{\mathrm{f}}$ & $94.60 \pm 0.01^{\mathrm{a}}$ & $0.65 \pm 0.02^{\mathrm{f}}$ & $6.44 \pm 0.01^{\mathrm{c}}$ \\
\hline $\mathrm{C}$ & 5 & $57.84 \pm 0.01^{\mathrm{c}}$ & $32.13 \pm 0.01^{\mathrm{a}}$ & $62.16 \pm 0.01^{\mathrm{a}}$ & $93.11 \pm 0.01^{\mathbf{b}}$ & $0.91 \pm 0.01^{\mathrm{c}}$ & $6.61 \pm 0.01^{\mathrm{a}}$ \\
\hline D & 5 & $51.35 \pm 0.01^{\mathrm{e}}$ & $23.99 \pm 0.01^{\mathrm{c}}$ & $48.80 \pm 0.01^{\mathrm{d}}$ & $92.88 \pm 0.01^{\mathrm{c}}$ & $0.79 \pm 0.01^{\mathrm{e}}$ & $6.56 \pm 0.01^{\mathrm{b}}$ \\
\hline $\mathbf{A}$ & 10 & $53.49 \pm 0.01^{\mathrm{d}}$ & $21.54 \pm 0.02^{\mathrm{e}}$ & $42.31 \pm 0.01^{\mathrm{f}}$ & $94.38 \pm 0.01^{\mathrm{a}}$ & $0.82 \pm 0.01^{\mathrm{c}}$ & $6.62 \pm 0.01^{\circ}$ \\
\hline B & 10 & $58.30 \pm 0.01^{c}$ & $29.70 \pm 0.02^{\mathrm{a}}$ & $57.38 \pm 0.01^{\mathrm{a}}$ & $94.26 \pm 0.01^{\mathrm{a}}$ & $0.81 \pm 0.01^{\mathrm{c}}$ & $6.72 \pm 0.01^{\mathrm{c}}$ \\
\hline $\mathrm{C}$ & 10 & $64.28 \pm 0.01^{\mathrm{a}}$ & $22.16 \pm 0.01^{\mathrm{d}}$ & $52.47 \pm 0.01^{\mathrm{c}}$ & $92.34 \pm 0.01^{\mathrm{b}}$ & $0.71 \pm 0.01^{\mathrm{d}}$ & $6.95 \pm 0.01^{\mathrm{a}}$ \\
\hline D & 10 & $45.55 \pm 0.01^{\mathrm{f}}$ & $22.03 \pm 0.01^{\mathrm{d}}$ & $43.33 \pm 0.01^{\mathrm{e}}$ & $91.42 \pm 0.01^{\mathrm{c}}$ & $0.83 \pm 0.01^{\mathfrak{c}}$ & $6.45 \pm 0.01^{\mathrm{e}}$ \\
\hline E & 10 & $56.96 \pm 0.01^{\mathrm{b}}$ & $23.08 \pm 0.01^{b}$ & $55.98 \pm 0.01^{\mathrm{b}}$ & $89.10 \pm 0.01^{\mathrm{e}}$ & $1.07 \pm 0.01^{\mathrm{a}}$ & $6.79 \pm 0.01^{\mathrm{b}}$ \\
\hline D & 15 & $53.89 \pm 0.01^{\mathrm{e}}$ & $23.24 \pm 0.01^{\mathrm{b}}$ & $49.89 \pm 0.01^{\mathrm{e}}$ & $91.00 \pm 0.01^{\mathrm{c}}$ & $0.83 \pm 0.01^{\mathrm{d}}$ & $6.48 \pm 0.01^{\circ}$ \\
\hline E & 15 & $56.74 \pm 0.01^{\mathrm{b}}$ & $22.07 \pm 0.01^{\mathrm{c}}$ & $52.53 \pm 0.01^{\mathrm{b}}$ & $88.46 \pm 0.01^{\mathrm{e}}$ & $1.17 \pm 0.01^{\mathrm{a}}$ & $6.81 \pm 0.01^{\mathrm{b}}$ \\
\hline $\mathbf{F}$ & 15 & $55.17 \pm 0.01^{\mathrm{d}}$ & $23.49 \pm 0.01^{b}$ & $53.19 \pm 0.01^{\mathrm{d}}$ & $92.16 \pm 0.01^{\mathrm{d}}$ & $0.83 \pm 0.01^{\mathrm{d}}$ & $6.34 \pm 0.01^{\mathrm{e}}$ \\
\hline A & 20 & \# & \# & $\#$ & $93.25 \pm 0.01^{\mathbf{b}}$ & $0.82 \pm 0.01^{\mathrm{c}}$ & $6.73 \pm 0.01^{\circ}$ \\
\hline B & 20 & $50.07 \pm 0.01^{\mathrm{e}}$ & $30.82 \pm 0.01^{\mathrm{a}}$ & $53.14 \pm 0.01^{\mathrm{b}}$ & $94.18 \pm 0.01^{\mathrm{a}}$ & $0.81 \pm 0.01^{\mathrm{c}}$ & $6.83 \pm 0.01^{\mathrm{b}}$ \\
\hline $\mathrm{C}$ & 20 & $62.05 \pm 0.02^{\mathrm{a}}$ & $24.80 \pm 0.01^{\mathrm{b}}$ & $56.14 \pm 0.01^{\mathrm{a}}$ & $92.29 \pm 0.01^{\mathrm{c}}$ & $0.70 \pm 0.01^{\mathrm{d}}$ & $7.08 \pm 0.01^{\mathrm{a}}$ \\
\hline D & 20 & $51.38 \pm 0.01^{\mathrm{d}}$ & $23.94 \pm 0.01^{\mathrm{c}}$ & $47.04 \pm 0.01^{\mathrm{e}}$ & $92.54 \pm 0.01^{\mathrm{c}}$ & $0.83 \pm 0.01^{\mathrm{c}}$ & $6.46 \pm 0.01^{\mathrm{e}}$ \\
\hline E & 20 & $56.23 \pm 0.01^{b}$ & $21.23 \pm 0.01^{\mathrm{e}}$ & $52.82 \pm 0.01^{\mathrm{c}}$ & $85.65 \pm 0.01^{\mathrm{e}}$ & $1.40 \pm 0.01^{\mathrm{a}}$ & $6.77 \pm 0.01^{\mathrm{c}}$ \\
\hline $\mathbf{F}$ & 20 & $52.56 \pm 0.01^{\mathrm{c}}$ & $22.16 \pm 0.01^{\mathrm{d}}$ & $48.64 \pm 0.01^{\mathrm{d}}$ & $90.57 \pm 0.01^{\mathrm{d}}$ & $0.94 \pm 0.01^{\mathrm{b}}$ & $6.42 \pm 0.01^{\mathrm{f}}$ \\
\hline
\end{tabular}

${ }^{*}$ Color analysis was not performed due to molding. ${ }^{1}$ Statistically significant difference was noted at $\mathrm{p} \leq 0.05$ level among mean values indicated with different letters in the same column.

Table 3. Results of microbiological analyses of pumpkin samples (log cfu/g).

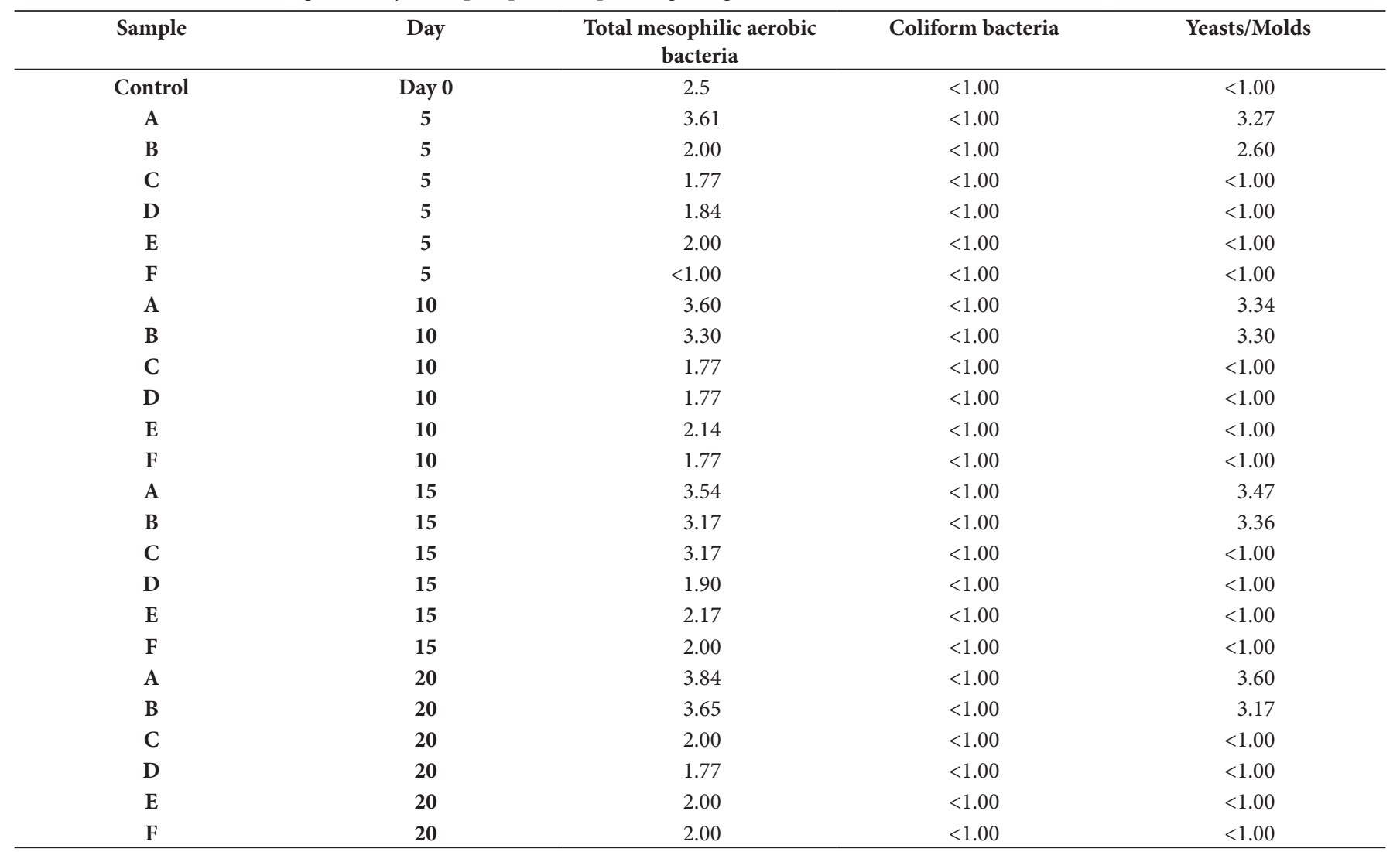


while moisture content, ash content and the $\mathrm{pH}$ value were found to be $94.58 \%, 0.72 \%$ and $6.54 \%$, respectively

$L^{*}$ value significantly decreased $(p \leq 0.05)$ at each 5 -day-interval during the storage period in the processed and packaged samples, in comparison with the control group. Likewise, statistically significant differences $(p \leq 0.05)$ were noted among the groups with respect to the $L^{*}$ values on the basis of LSD Test results (Table 2). On the other hand, the lowest level for $L^{*}$ value was obtained on day 20. Among all groups, statistically highest $L^{*}$ value was achieved in group $C$, which was coated with zein film and packaged in polystyrene plates with PVC stretch, whereas the highest $a^{*}$ and $b^{*}$ values were obtained for the pumpkin samples in group B (vacuum packaged in PVDC film with no coating) at the end of the storage period.

$L^{*}$ value decreased in the samples processed with edible coating films, which resulted in darkening and loss of brightness. On the other hand, $\mathrm{a}^{*}$ and $\mathrm{b}^{\star}$ values increased in all groups and the pumpkin samples turned deep red and yellow during the storage period. At the end of the storage period, $a^{*}$ and $b^{*}$ values exhibited the lowest levels in group $\mathrm{E}$ (processed with zein+benzoic acid coating and packaged in polystyrene plates with PVC stretch) and group F (processed with zein+benzoic acid coating and vacuum packaged in PVDC), in comparison with those of the other groups. $a^{*}$ values in groups $\mathrm{C}$ and $\mathrm{D}$ (zein-coated and packaged in polystyrene plates with PVC stretch/zein-coated and vacuum packaged in PVDC film) were similar on days 10 and 15.

When the pumpkin samples were evaluated in terms of moisture content, the initial value $(94.58 \%)$ in the control group, decreased by time to $93.25 \%$ on day 20 in the samples which were packaged in PVC stretch without any processing procedure (Group A). The lowest moisture content $(85.65 \%)$ was encountered in group $\mathrm{E}$, which was treated with zein+benzoic acid and packaged in polystyrene plates with PVC stretch. Benzoic acid was found to have increased dry matter and thus decreased moisture content, which indicated that neither processing nor packaging protocols prevented this loss. Since groups A and B were not pretreated with any coating solutions, no statistically significant difference $(p>0.05)$ was noted in terms of moisture content even on day 10. Similarly, zein-coated groups, $C$ and $D$ revealed no statistically significant difference $(p>0.05)$ with respect to moisture content after 10 days.

In terms of ash content of the samples, a statistically significant difference $(\mathrm{p} \leq 0.05)$ was observed at the $5^{\text {th }}$ day of the storage which revealed similar results by progressing time. Likewise, no statistically significant difference ( $p>0.05$ ) was noted between group A and group B after 5 days of storage. The highest levels of ash content $(0.94 \%$ to $1.40 \%)$ were detected in groups $\mathrm{E}$ and F on day 20. Presence of benzoic acid increased the ash content of the samples in these groups.

The initial $\mathrm{pH}$ value (6.46) in the control group, increased to 6.73 in group A, which were packaged in PVC stretch without any processing procedure, at the end of the storage period. The lowest $\mathrm{pH}$ value (6.42) was measured in the group F (zein+benzoic acid coated and vacuum packaged in PVDC film. Benzoic acid was proven effective in lowering $\mathrm{pH}$ level. Statistically significant difference $(p \leq 0.05)$ was observed among all groups in terms of $\mathrm{pH}$ level on days 10 and 20. Furthermore, no statistical significance $(p>0.05)$ was noted between groups A and B and among groups $\mathrm{D}, \mathrm{E}$ and $\mathrm{F}$ on day 5. Likewise, similar results were obtained between groups B and $\mathrm{E}$ on day $15(p>0.05)$.

The initial load of total mesophilic aerobic bacteria (TMAB) of non-treated pumpkin samples were estimated at $2.5 \log \mathrm{cfu} / \mathrm{g}$ level, while this value reached to the highest point (3.84 log cfu/g) in the samples of day 20 in group A (which were packaged in PVC stretch without any processing procedure). The lowest count of TMAB with $<1.00 \mathrm{log}$ cfu/g level belonged to the samples on day 5 in group $\mathrm{F}$.

The initial coliform load $(<1.00 \log \mathrm{cfu} / \mathrm{g})$ of the samples maintained this level during the whole storage period. The initial load of yeasts/molds at $<1.00 \log \mathrm{cfu} / \mathrm{g}$ level reached to the highest quantity (3.60 log cfu/g) in group A on day 20 when compared with those of other groups which received different processing and packaging procedures. Yeasts-molds load sustained at $<1.00 \log \mathrm{cfu} / \mathrm{g}$ level in groups C, D, E and F between 5 to 20 -day intervals. However, massive molding was observed in groups A and B, particularly on days 15 and 20 .

\section{Discussion}

Zein is a commercially available edible coating protein and is industrially derived from corn gluten. It is soluble in water at high and low $\mathrm{pH}$ levels due to the high content of amino acids. Zein coating gives the product a shiny appearance and a firm texture (Gennadios \& Weller, 1990). It has better moisture barrier properties (Kester \& Fennema, 1986). Zein is used in pharmaceutical industry, as well, as a capsule coating material to protect the integrity of the product and for masking the taste and odor of the drugs (Gennadios et al., 1994) Coating of the roasted peanuts with zein serves as an oxygen barrier and prevents molding and souring and the rancid taste in the food and also it prolongs the shelf-life of the product up to 50\% (Krochta \& Mulder, 1997).

In this study, our aim was to investigate the effects of zein coating on the quality of sliced pumpkin during the cold storage $\left(4^{\circ} \mathrm{C}\right)$ of the product. On the basis of our findings, zein did not function as effectively as was expected against moisture loss of the product during the storage and did not lead to prominent changes in ash content and $\mathrm{pH}$ levels. After the $15^{\text {th }}$ day of the storage period massive molding was observed in the control samples which were stored in polystyrene plates with polyethylene film and thus color measurements were unable to be performed. Besides, the same samples exhibited the lowest mean values in terms of color parameters $\left(L^{*}, a^{*}, b^{*}\right)$ during the whole storage procedure.

When TMAB load was evaluated on the basis of microbiologic analysis, zein coating together with vacuum packaging in PVDC reduced microbial load in a controlled manner and showed marked effectiveness against molding. No increase was noted in yeasts/molds levels in these samples which might readily have been associated with the effectiveness of the material as an oxygen barrier, as well. 
Different studies, regarding the changes in quality parameters are available for processing pumpkin products with different coating materials. Lago-Vanzela et al. (2013) investigated the levels of provitamin A in dried pumpkin which was processed with natural and modified starch. Their results revealed remarkable improvement in carotenoid levels of natural corn starch-coated pumpkins which were dried at $90^{\circ} \mathrm{C}$, in contrast with substantial loss of trans- $\alpha$ and trans- $\beta$-carotene in unprocessed samples.

Moreira et al. (2009) investigated the effects of different drying conditions $\left(100 \mathrm{~min}\right.$ at $20^{\circ} \mathrm{C}, 50 \mathrm{~min}$ at $30^{\circ} \mathrm{C}$ and $30 \mathrm{~min}$ at $50^{\circ} \mathrm{C}$ ) and the type of the coating material in sliced pumpkins coated with solutions containing chitosan (2\%) carboximethylcelulose $(0.75 \%)$ and sodium caseinate $(5 \%)$ on the microbiologic quality parameters of the product. According to their findings no significant reduction was recorded with respect to the count of TMAB in sodium caseinate and carboximethylcelulose-coated samples when compared with the untreated pumpkins. TMAB count was reduced approximately by $1.00 \mathrm{log}$ level in the samples which were treated with chitosan and subsequently subjected to a drying process at $50{ }^{\circ} \mathrm{C}$ for $30 \mathrm{~min}$. The effect of chitosan-based coating on TMAB in pumpkin samples was compatible with our findings.

Cetin (2015) investigated the changes of quality parameters in pumpkin samples which were processed with different solutions (calcium citrate, calcium ascorbate and calcium citrate+ calcium ascorbate) and subjected to either vacuum packaging or modified atmospheric packaging (MAP) with a storage period of 28 days. No marked changes were observed in $\mathrm{pH}$ level, acidity and water-soluble dry material amount until the $21^{\text {st }}$ day of the storage but the changes revealed statistically significant results on day 28. Coloration parameters $\left(L^{\star} \cdot a^{\star} \cdot b^{\star}\right)$ were reduced with storage in all groups. The products expired on day 14 which was an evidence for an increase in total count of bacteria and also for coliform bacteria, whereas samples packaged under modified atmospheric pressure and those that were vacuum packaged expired on day 21 and on day 28, respectively. The pumpkin samples in the control group of our study became inconsumable on day 15 as a result of the increase in total bacterial load and massive molding, which was consistent with the findings of this research.

There are studies available regarding the changes in quality parameters during storage for zein-coated fruits and vegetables. Baysal et al. (2009) initially coated intermediate moisture tomatoes with zein in combination with sorbate and ascorbate and then investigated the changes at two different storage temperatures $\left(5^{\circ} \mathrm{C}\right.$ and $20^{\circ} \mathrm{C}$ ). Moisture loss was noted both in the control and in the processed groups but moisture loss of coated tomatoes was less than that of uncoated samples. Besides, these two temperature-based storage protocols in treated samples with different film coatings exhibited no statistically significant change in terms of acidity of the product. Coloration measurements were performed as well and zein coating was found ineffective. Likewise, no significant difference was detected among the groups in terms of TMAB. The temperature change did not alter the count of TMAB but did the storage period which was statistically significant $(p<0.05)$. The reason that the moisture loss of this study was lower than that of our study might be associated with the lack of a hard outer shell layer in our samples, which caused the penetration of the alcohol solution in which zein film was prepared, into the pumpkin tissue and thus reduced moisture content.

In another study, Baysal et al. (2010) coated intermediate moisture apricots with antimicrobial and antioxidant added zein film and stored the products at $5{ }^{\circ} \mathrm{C}$ and $20^{\circ} \mathrm{C}$. Microbial growth and coloration were detected to have been delayed in zein-coated samples at the end of the procedure. It was particularly indicated that moisture loss of coated samples was less than that of uncoated apricots which were exposed to high-temperature storage, however the effect of coating was far from being noteworthy at low temperature. That the zein-based coating process delayed bacterial growth according to our findings, was similar with the results of this study.

\section{Conclusion}

In the study zein and zein+antimicrobial agent-coated sliced pumpkins were packaged with different methods and stored at $4{ }^{\circ} \mathrm{C}$ to be evaluated in terms of certain quality parameters. Zein film, alone was proven ineffective against moisture loss and vacuum packaging revealed more significant results regarding this parameter. $a^{\star}$ and $b^{\star}$ values were increased in all groups while $\mathrm{L}^{\star}$ (lightness) values decreased which gave a dull appearance to the products. The lowest $\mathrm{L}^{*}$ values were observed in group A, which was packaged in polystyrene plate with PVC stretch film and the highest $\mathrm{L}^{*}$ values were achieved in group C (zein film pretreatment + polystyrene plate with PVC stretch film packaging) and group $\mathrm{E}$ (zein+benzoic acid pretreatment+polystyrene plate with PVC stretch film packaging). Furthermore, pretreatment with edible coating in combination with different methods of packaging prevented the increase of the microbial load and thus inhibited molding.

There are ongoing studies with respect to the effects of edible coating materials. Further technologic developments in food industry will enable different edible films and coating materials to be widely used on food products. Therefore, while troubles with manufacturer merchandise due to short expiry dates of the products have been resolved to some extent, consumer demand will eventually be fulfilled by prolonged shelf-life of the products.

\section{References}

Association of Official Analytical Chemists - AOAC. (1984). Official methods of analysis (14th ed.). Washington: AOAC.

Association of Official Analytical Chemists - AOAC. (1990). Official methods of analyses of Association of Analytical Chemist (15th ed.). Washington: AOAC.

Balkaya, A., Ozbakır, M., \& Karaağaç, O. (2010). Evaluation of variation and fruit characterization of pumpkin (Cucurbita moschata Duch.) populations collected from Black Sea Region. The Journal of Agricultural Science, 16, 17-25.

Baysal, T., Ersus Bilek, S., \& Apaydın, E. (2010). The effect of corn zein edible film coating on intermediate moisture apricot (Prunus Armenica L.) quality. Gida, 35(4), 245-249.

Baysal, T., Ersus, S., \& Apaydın, E. (2009). The effect of corn zein edible film coating on quality of intermediate moisture tomatoes. Gida, 34(6), 359-366. 
Cetin, R. U. (2015). Quality changes and shelf-life determination of modified atmosphere packaged fresh-cut pumpkin slices. Isparta: Suleyman Demirel University.

Gennadios, A., \& Weller, C. L. (1990). Edible films and coatings from wheat and corn proteins. Food Technology, 44(10), 63-69.

Gennadios, A., Park, H. J., \& Weller, C. L. (1994). Relative humidity and temperature effects on tensile strength of edible protein and cellulose ether films. Transactions of the ASAE, 36(6), 1867-1872. http://dx.doi.org/10.13031/2013.28535.

Guilbert, S., Gontard, N., \& Gorris, L. G. M. (1996). Prolongation of the shelf-life of perishable food products using biodegradable films and coatings. LWT - Food Science Technology, 29(1-2), 10-17. http:// dx.doi.org/10.1006/fstl.1996.0002.

Guine, R. P. F., Pinho, S., \& Barroca, M. J. (2011). Study of the convective drying of pumpkin (Cucurbita maxima). Food and Bioproducts Processing, 89(4), 422-428. http://dx.doi.org/10.1016/j.fbp.2010.09.001.

Gurbuz, D., \& Evranuz, E. O. (2006). The effect of drying kinetics of salt addition the sugar solution in osmotic drying pumpkin. In Proceedings of the 9th Food Congress, Bolu, Turkey.

Harrigan, W. F. (1998). Laboratory methods in food microbiology (3rd ed.). London: Academic Press.

Işık, H., Dağhan, Ş., \& Gokmen, S. (2013). A study on edible coatings used in food industry. Electronic Journal of Food Technologies, 8(1), 26-35.

Kester, J. J., \& Fennema, O. (1986). Edible films and coatings: a review. Food Technology, 40(12), 47-59.
Krochta, J. M., \& Mulder, J. C. (1997). An update on edible films. Lifeline, 15(2), 1-3.

Lago-Vanzela, E. S., Do Nascimento, P., Fontes, E. A. F., Mauro, M. A., \& Kimura, M. (2013). Edible coatings from native and modified starches retain carotenoids in pumpkin during drying. Food Science Technology-Leb, 50(2), 420-425. http://dx.doi.org/10.1016/j. lwt.2012.09.003.

Moreira, M. D. R., Ponce, A., Del Valle, C. E., \& Roura, S. I. (2009). Edible coatings on fresh squash slices effect of film drying temperature on the nutritional and microbiological quality. Journal of Food Processing and Preservation, 33, 226-236. http://dx.doi.org/10.1111/j.17454549.2008.00295. $\mathrm{x}$

Oloyede, F. M., Agbaje, G. O., Obuotor, E. M., \& Obisesan, I. O. (2012). Nutritional and antioxidant profiles of pumpkin (Cucurbita pepo Linn.) immature and mature fruits as influenced by NPK fertilizer. Food Chemistry, 135(2), 460-463. http://dx.doi.org/10.1016/j. foodchem.2012.04.124. PMid:22868114.

SAS Institute Inc. - SAS. (2007). Statistical discovery from SAS. Cary: SAS

Torlak, E., \& Nizamlioglu, M. (2011). Effectiveness of edible chitosan films containing essential oils on Staphylococcus aureus and Escherichia coli O157:H7. Kafkas Universitesi Veteriner Fakultesi Dergisi, 17(Suppl A), 125-129.

Zhong, Y., Cavender, G., \& Zhao, Y. (2014). Investigation of different coating application methods on the performance of edible coatings on mozzarella cheese. LWT - Food Science and Technology, 56(1), 1-8. http://dx.doi.org/10.1016/j.lwt.2013.11.006. 